\title{
Bulletin of the School of Oriental and African Studies
}

http://journals.cambridge.org/BSO

Additional services for Bulletin of the School of Oriental and African Studies:

Email alerts: Click here

Subscriptions: $\underline{\text { Click here }}$

Commercial reprints: $\underline{\text { Click here }}$

Terms of use : $\underline{\text { Click here }}$

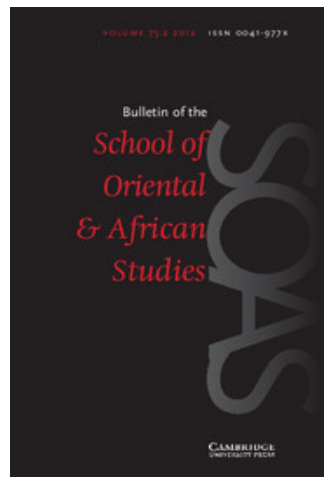

\section{Tibetan gseb and Cognate Words}

\author{
Walter Simon
}

Bulletin of the School of Oriental and African Studies / Volume 20 / February 1957, pp 523 532

DOI: 10.1017/S0041977X00062078, Published online: 24 December 2009

Link to this article: http://journals.cambridge.org/abstract S0041977X00062078

How to cite this article:

Walter Simon (1957). Tibetan gseb and Cognate Words. Bulletin of the School of Oriental and African Studies, 20, pp 523-532 doi:10.1017/S0041977X00062078

Request Permissions : $\underline{\text { Click here }}$ 


\title{
TIBETAN GSEB AND COGNATE WORDS
}

\author{
By Walter Simon
}

I

$\mathrm{T}^{\mathrm{T}}$ HE entry gseb in Jäschke's Tibetan dictionary, ${ }^{1}$ which has been taken over almost without a change into that compiled by Sarat Chandra Das, ${ }^{2}$ poses a problem in so far as it differs in an important point from the entries to be found in the dictionaries of A. Csoma de Körös, ${ }^{3}$ I. J. Schmidt, ${ }^{4}$ and that of the Catholic Missionaries of 'Tibet, generally referred to as Desgodins' dictionary. ${ }^{5}$ While all these dictionaries are in agreement on the meaning of 'stallion', which has been listed by $\mathrm{J}($ äschke) under I, the difference occurs in the treatment of $g s e b$ (alternating with $s e b$ ), listed by J under II. The definitions are as follows :

(i) Csoma :

(a) (p. 296)

$\left.\begin{array}{l}\text { seb } \\ k h r o d\end{array}\right\} s$. assemblage, crowd, crew; heap, pile, rick, stack

$\left.\begin{array}{l}\text { seb lam } \\ \text { gsan̂ lam }\end{array}\right\}$ a short cut, a secret way or road

(b) (p. 38)

gseb a heap, pile, crowd, assemblage

(ii) Schmidt :

(a) (p. 596)

seb oder khrod Menge, Gedränge, ein Haufe, eine Ansammlung; ein Stoss, Schober

seb lam ein kurzer Strich, ein heimlicher Weg gsân lam idem

(b) (p. 612)

gseb ein Haufen, eine Ansammlung etc. ; s. seb

(iii) Desgodins ${ }^{6}$ :

(a) (p. 1023)

seb, gseb $=$ khrod $\quad$ rassemblement, réunion

gseb lam = gsân lam carrefour, route secrète

(b) (p. 1049)

gseb, seb troupe, tas, rassemblement

hkhrigs gseb réunir ensemble, condenser

1 H. A. Jäschke, A Tibetan-English dictionary, London, 188 I ('eprinted 1934).

2 Tibetan-English dictionary, Calcutta, 1902, p. 1309.

3 Essay towards a dictionary, Tibetan and English, Calcutta, 1834.

4 Tibetisch-deutsches Wörterbuch, St. Petersburg, 1841.

5 Dictionnaire thibétain-latin-français par les Missionnaires catholiques du Thibet, Hongkong, 1899.

${ }^{6}$ I have omitted the Latin definitions. 
grôn gseb villages dont les maisons sont contigues dmag gseb armée

(iv) Jäschke (p. 590)

II. also $s e b$,

1. the narrow INTERstices between persons or things thronged together, hence with $n a$, $t u$, and $l a$, BETWEEN, AMONG, with nas FROM BETWEEN

(1 1) khyi mihi gseb la mchôn the dog leaps into the midst of the people ${ }^{2}$

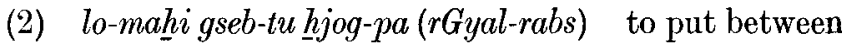
leaves

(3) sprin-gyi gseb-nas lus phyed hthon ${ }^{3}$ (rGyal-rabs) half of his body protrudes from between the clouds $=$ rises above, etc.

(4) grô̂-gseb-tu bźugs-pa (Milaraspa) to sit among the villagers

(5) khyed-cag-gi gseb-na Meu-dgal bya-bahi bud-med yoddam? is there a woman among you named Meu-dgal?

gseb-lam a secret path, by-way, between rocks or underwood

2. multitude, crowd

$\begin{array}{ll}\text { dmag-gseb } & \text { army } \\ n a g s-g s e b^{4} & \text { forest }\end{array}$

Before elaborating the difference in the treatment of gseb by $\mathrm{J}$ and the other lexicographers it is necessary to realize that this difference is primarily one between Csoma and J, since Schmidt merely translated Csoma's definitions into German and Desgodins' dictionary appeared later than J's. The difference may be summarized as follows:

(1) J introduces the new meaning of 'narrow interstices', which he illustrates by as many as five examples.

1 I have numbered the examples, adding at the same time the sources from the German edition of J's dictionary (Handworterbuch der tibetischen Sprache, Gnadau, 1871, p. 614), which have apparently dropped out in the process of preparing the English version. I take this opportunity of mentioning another omission in the English edition. On p. xxi under 'Abbreviations' add : Lt. = Lhan-thabs, a medical work, No. 475 of the 'Verzeichnis' by [I. J.] Schmidt [and o. Böhtlingk (Bulletin de la Classe des Sciences historiques, philologiques et politiques de l'Académie Imp. des Sciences de St. Pétersbourg, IV, 1848, col. 117)]. See now about this work, whose full title begins with Bdud-rtsi snyin̂-po yan-lag brgyad-pa gsan̂-ba man-ñag yon-tan rgyud-kyi lhanthabs, (and its Mongolian version), i.a. W. Heissig, Die Pekinger lamaistischen Blockdrucke in mongolischer Sprache, Wiesbaden, 1954, pp. 96, etc., and the notes by J. W. de Jong in his review of the latter work in T'oung Pao, xuII, 1955, 313 4. See also J, Dictionary, p. 601, s.v. lhan-pa.

2 This example, which refers to a mad dog, reoccurs s.v. mchon (p. 166) as mi-seb-la (mchon) and there is translated as ' among the people'.

3 The example reoccurs s.v. sprin (p. 336).

4 The compound reoccurs s.v. nags (p. 300) where it is translated as ' an intersected forest'. See also below, p. 525, 11.2 . 
(2) J retains the meaning of 'crowd', given by Csoma, but omits the meanings of ' assemblage, heap, pile, rick, stack'.

(3) $\mathrm{J}$ retains the example gseb-lam with the interesting addition 'between rocks or underwood'.

(4) J ignores the existence of the synonymous khrod.

(5) In introducing his new meaning, $\mathbf{J}$ is apparently unconcerned with the semasiological difficulty he creates when assigning to one and the same word meanings as far apart as 'small interstices' on the one hand and 'multitude, crowd' on the other.

I wish to make the following additional comments :

ad (1) Our examination must start with the five examples which $\mathrm{J}$ adduces in support of the meaning of 'small interstices'. It would appear that the meanings adduced by Csoma suffice to account for them, viz. the meaning of 'crowd' in the case of exx. $1,4,{ }^{1}$ and 5 , the meaning of 'pile' in the case of ex. 2, and that of 'assemblage' in the case of ex. 3 .

ad (2) Of the two examples which serve to illustrate the meaning of ' multitude, crowd' and which were retained by $J$, the second (nags-gseb) must at some time have been understood by him as an example belonging to II, 1 since s.v. nags he translates this compound as ' intersected forest'.

ad (3) The addition is interesting as it clearly underlines the meaning of '(space) between'.

ad (4) J defines khrod (p. 52) as 'crowd, assemblage, mass, multitude'. Csoma (p. 16) has 'assemblage, crowd; pile, heap; rick, stack, etc. '. Among the examples adduced by J, we find nagskhrod 'dense forest' (previously translated by Csoma (p. 77) as ' an assemblage of forest'), and an example (from the rGyal$r a b s$ ) which is, in fact, very reminiscent of J's examples illustrating the use of gseb: dehi khrod-du lha-gcig hjog-pas 'placing the princess among their (the girls') company'. J's entry concludes with the very illuminating remark 'In Western Tibet khrod-

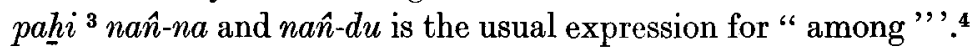

Both the usage of khrod in present-day Western Tibet and the example adduced from the rGyal-rabs constitute striking parallels to the usage of gseb. There is no doubt that they would have prevented a lexicographer of the calibre of $\mathrm{J}$ from introducing his new meaning if he had been aware of their existence.

\footnotetext{
1 J evidently understands groñ-gseb-tu as short for gron̂-pohi gseb-tu.

a See above, p. 524, n. 4. In the reprint of J's entry in S. C. Das' dictionary gseb-nags is translated as 'dense forest'.

${ }^{3}$ I have substituted khrod-pahi for the dialectal t'o-pai.

4 ef. also English among from O.E. on gemang, lit. 'into a crowd'. (See, e.g., H. C. Wyld, The universal dictionary of the English language, London, 1932, p. 32.)
} 
In fact, we may safely assume that this was not the case and that at that time $\mathrm{J}$ had not seen Csoma's definitions either. Evidence to this effect is provided by the entries khrod and gseb in J's lithographed Romanized Tibetan and English dictionary of 1866.' The entry khrod (thod) consists merely of the meanings ' multitude, crowd; great number'. On the other hand, the entry gseb reads as follows :

seb I $(g) s e b$ the interstices between the individuals of a multitude of persons or things. lam, byway between rocks or trees; -na among, between : na (nas), from among

II gseb a male horse or camel

A comparison of this first draft of the entry gseb in 1866 with its final form in J's dictionary of 1881 justifies the assumption that $J$ arrived at his meaning of 'interstices' at an early stage of his lexicographical work, wrongly deducing it from such combinations with gseb as gseb-na 'between' and gsebnas 'from among', unaware of other usages of gseb, and independently of Csoma. Consultation, at a later stage, of Csoma's dictionary induced him merely to make a short addition in both the German edition of 1871 and the English edition of 1881, where he limited himself to the meanings of " multitude, crowd' (or, for that matter, 'Haufe, Menge ') listed under II, 2. When doing so, he was apparently also unaware of the semasiological difficulty he was thereby creating and furthermore overlooked the fact that of the two examples in the English edition, ${ }^{2}$ viz. dmag-gseb and nags-gseb, the latter had been explained by him under nags as 'intersected forest', a definition which clearly recalls the 'interstices'. So the parallelism between gseb and khrod was bound to escape $J$, nor can he have been aware at that time of the dialectal usage of khrod, mentioned in the 1881 version of his dictionary.

ad (5) While it is important to note the serious semasiological difficulty created by introducing the meaning of 'small interstices', it is equally important to stress the qualification which $\mathbf{J}$ adds to this meaning, viz. 'between persons or things thronged together',3 and the inference he draws therefrom, viz. " hence with $n a, t u$, and la between, among, with nas from between'. It is easy to see that "the state of being close together or thronged together' is a common characteristic of whatever constitutes ' an assemblage, a crowd, a crew, a heap, a pile, a rick, a stack', to repeat Csoma's definitions of gseb, and, as has been pointed out under ad (1), the examples adduced by $\mathrm{J}$ to illustrate the meanings of 'between, among' and 'from between' can just as well be accounted for by accepting Csoma's meanings, as by proposing the meaning of 'small interstices' postulated by $\mathrm{J}$.

1 Kyelang in British Lahoul, 1866, pp. 132 and 103.

2 The German edition has only dmag-gseb, the meaning of which J queries : 'Heer (?) '.

3 The italics are mine. 
In the light of the preceding discussion it would therefore seem justifiable to abandon this latter meaning, but before doing so we must consider the examples given by two Tibetan scholars who, evidently under the influence of $\mathrm{J}$, have assigned to $g s e b$ similar meanings (II). It will also be necessary to adduce a number of further examples to illustrate the usage of $g s e b$ (III).

The two meanings in question are 'space between' and 'narrow interspace '. The former ('Zwischenraum ') is given by A. Grünwedel in his glossary to his Legenden des Na-ro-pa, ${ }^{1}$ the latter by F. W. Thomas in the glossary which constitutes Part III of his Tibetan literary texts and documents concerning Chinese Turkestan.2

Of Grünwedel's two examples the first, listed here as No. 6, recalls No. 4, speaking as it does of a 'crowd of children', the second (No. 7) shows gseb as synonymous with Tibetan $p h u \hat{n}-p o$ ' heap ', which usually occurs in combination with me 'fire' to render Sanskrit agniskandha ${ }^{3}$ :

(6) . . . byis-pa-rnams-kyi bseb-tu bźugs-nas (. . . befand er sich mitten unter den Kindern (p. 137)).

(7) the-tshom med-par mehi bseb-tu rgyan̂s hphyon̂s (- mchon̂s) pas (und sprang ohne Bedenken mit ausgebreiteten Beinen mitten in das Feuer (p. 102)).

The two passages referred to by F. W. Thomas ${ }^{4}$ are practically identical. They describe the emission of rays ' from the juncture of the brows' :

(8) . . . smin-mtshams-kyi gseb-nas de-bźin-gśegs-pahi ḩod-zer-rnams byun̂-n̂o (from the juncture of his brows came forth the lights called 'Tathāgata-form ').

A similar sentence (with a number of variants) has been included in the Mahāvyutpatti ${ }^{\mathbf{5}}$ :

(9) dbuhi gtsug-tor gseb-nas hod-zer byun-nas.

Its Sanskrit equivalent uṣņ̄ṣa-vivarāntarād raśmir niścarati would permit the reconstruction $b h r \bar{u}$-vivarāntarād ${ }^{6}$ if the original language of the 'Inquiry of Vimalaprabhā' was, in fact, Sanskrit." While vivarāntarād confirms the meaning of 'from between' for gseb-nas it does not, of course, invalidate the

1 Leipzig, 1933, p. 232, s.v. bseb. bseb-tu 'dazwischen hinein '.

2 London, 1955, p. 190.

${ }^{3}$ See, e.g., Mahãvyutpatti (Sakaki), No. 224. A further example occurs in the Tibetan translation of the passage sacet te mahaty agni-skandhe prapateyuh in the beginning of chapter XxIV of the Saddharmapundarika-Sütra: gal-te mehi phun̂-po chen-por lhun̂n-nahañ (Narthang Kanjur, mDo, $\left.J a, 255 B^{7}\right)$. See also below ex. No. 10.

4 loc. cit., Part I, 1935, pp. 182 and 248 (Narthang Kanjur, $m D o, P a$, p. 342A $\mathrm{A}^{1}$ and $408 \mathrm{~B}^{2-3}$ ).

5 loc. cit., No. 6293, see also Nos. 6301 and 6346 .

6 ef. also Saddharmapundarika (ed. by U. Wogihara and C. Tsuchida, Tokyo, 1934, p. 4, 11. 18-19) : bhrūvivarāntarād ūrṇākośäd ekā raśmir niścaritā. Narthang Kanjur, mDo, Ja,

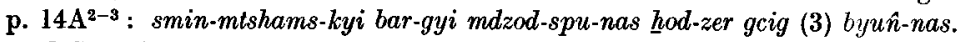

7 See, about this question, Thomas, loc. cit., I, p. 141. 
meanings of ' assemblage', etc., for gseb nor permit the mechanical equating of gseb with vivara. ${ }^{1}$ In ex. 8 gseb seems to stress the density of the brows, as it were 'from within the density of the juncture of the brows'.

\section{III}

Before passing on to cognate words it will be necessary to illustrate the meaning of gseb by further examples. The combination with me 'fire', which we witnessed in ex. 7, occurs, e.g., also in the Commentary to the Subhāsitaratnanidhi by dMar-sTon Chos-rGyal, which is entitled Legs-par bsad-pa rin-pochehi gter mdzod ${ }^{2}$ :

(10) mehi gseb-na gnas-pa (p. 68B 1 ).

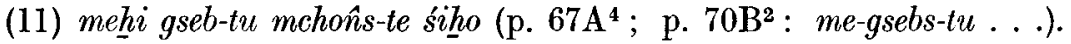

The combination with nags ' forest' ${ }^{3}$ occurs in the same text on p. $68 \mathrm{~A}^{6}$ in relation to a hermit living ' in the thickness' of a forest :

(12) nags-kyi gseb-na gnas-pahi dran̂-srôn.

The story about a bat installing itself in (lit. entering) 'the thickness' of the plumage of a vulture shows a combination with spu ' hair, plumage':

(13) pha-wan̂-gis rgod-pohi spu-gseb-du źugs-te (p. 66. ${ }^{1}$ ).

The combination with sprin (in 'the thickness' of the clouds) occurs in the 'Avadāna de l'oiseau Nīlakantha' in a sentence almost identical with J's example 3 :

(14) . . . lhahi bu dkar-po lus-phyed sprin-gseb-tu nub-cin, lus phyed hthonpa źig (. . . le fils d'un dieu, une moitié du corps dans les nages, l'autre moitié émergeant) ${ }^{4}$.

gseb occurs, furthermore, in combination with tshal ' wood, grove', a synonym of nags 'forest', with which it can also be combined (nags-tshal). The meaning of gseb has also been understood as 'thickness' by L. Feer, who translates $^{5}$

(15) ltan̂-brân-gi tshal gseb-tu (Narthang Kanjur, $m D u l, K a, 188 \mathrm{~A}^{4}$, and also $K a$, p. $43 \mathrm{~B}^{4}$ )

as 'dans l'épaisse forêt de Yasti' (= Yașțivana, Lațthivana).

Apart from two similar passages which show tshal-gseb in combination with ral- (for ras-) bal-can, ${ }^{6}$ which translates Karpāsika, ${ }^{7}$ and śar-pa, ${ }^{8}$ which refers to Yaștīi, the following passage, which gives a transcription of Karpāsika,

1 See below, p. 529, n. 2.

2 No. 40890 of the Tibetan Collection in the Library of the School of Oriental and African Studies. No place, no date, 104 pp.

3 cf. above, p. 525, the translation by $J$ of nags-khrod as 'dense forest'; see also p. 525, n. 2.

4 See J. Bacot, La vie de Marpa, Paris, 1937, pp. 113 and 70.

5 Fragments extraits du Kandjour, traduits du tibétain (Annales du Musée Guimet, Vol. v, 1883), p. 98 ; see also ibid., pp. 10 and 42, and notes 2 and 5 on p. 42 .

6 mDul, Ka, 43B : ral-bal-can-gyi tshal-gseb-tu gśegs-nas. See Feer, loc. cit., p. 10.

7 See Feer, loc. cit., p. 42, and n. 2.

8 mDul, Cha, 100D?; śar-pahi tshal-gseb-tu gśegs-nas.

' See Feer, p. 42 and n. 5. Feer translates 'dans l'épaisse forêt de l'Est' and remarks (n. 5) 'Dans les livres pâlis elle est appelée la forêt de Yaști'. Earlier, in his Études bouddhiques, II, 1875 , p. 68, n. 1, he translated the passage 'dans le jardin abondamment planté de l'Est '. 
or rather of a form corresponding to Pali Kappāsiya, ${ }^{1}$ is of special interest in so far as gseb, at least in some variants of the passage, occurs by itself, i.e. not preceded by tshal, in the meaning of tshal-gseb, and would therefore seem to justify the addition of the meaning of 'thicket' to Csoma's definitions of $g s e b$. In view of the Pali form Kappasiya-vanasanda the Sanskrit word corresponding to gseb is likely to have been sanda (khanda), which on its part is also rendered by khrod. ${ }^{2}$ The suggested meaning of 'thicket' would allow us to explain the compound gseb-lam as 'path through a thicket', which meaning would be quite in agreement with J's definition ${ }^{3}$ as far as ' underwood' is concerned.

The passage occurs in chapter XxvII of the Tibetan version of the Vinayavibhanga. Both the Narthang print of the Kanjur and the MS Kanjur of the British Museum show the following reading :

$m D u l, C h a$, p. $100 \mathrm{~B}^{4}$ (B.M. MS, $m D u l, K h a$, p. $105 \mathrm{~B}^{6}$ )

(16) Kar-ba-sihi gseb-tu gśegs-nas.

The Derge print has Kar-pa-sihi tshal-gseb-tu ( $m D u l, C h a$, p. $\left.68 \mathrm{~B}^{1}\right)$, whereas the Lhasa Kanjur shows again gseb-tu instead of tshal-gseb-tu. However, instead of Kar-ba-sihi $i$, the latter print has $V \bar{a}-r a-n \bar{a}-s i h i\left(m D u l, C h a\right.$, p. $\left.95 \mathrm{~A}^{5}\right)$. The reading of the Peking Kanjur ${ }^{4}$ is Kar-ba-sihi tshal-gseb-tu (Vol. Je, p. 63A ${ }^{6}$ ).

Example 16 concludes the list of additional examples.

I regret, I am unable to offer an example from actual texts of the compound hkhhrigs-gseb, which has been included in Desgodins' dictionary. ${ }^{5}$ As is evident from the meaning of ' to assemble, to condense', attributed to the compound, we are dealing here with a (causative) verb gseb meaning " to bring about the state of being close together'. As such the verb gseb would in fact be similar in meaning to gsob-pa (see below, Section IV, No. II $(a)$ 1) 'to fill out or up' (to throng). The existence of such a verb also throws light on the two compounds which illustrate the meaning of 'stallion', viz. rta-gseb and rna-gseb (male

1 cf. G. P. Malalasekera, Dictionary of Pãli proper names, II, London, 1938, p. 772.

2 ef. Mahävyutpatti, No, 4214 vana-khanda (vanaşanda) = nags-khrod. In the Suvarnaprabhäsa-sütra, nags-khrod is used to render vanavivara (see J. Nobel, SuvarnaprabhäsottamaSütra, II, Leiden, 1950, p. 18. vivara, on the other hand, is given as equivalent for gseb in the compound nags-gseb on p. 97 (folio $190 \mathrm{~A}^{1}$ ) of the Dictionnaire tibetain-sanscrit by Tse-RingOuang-Gyal, edited by Professor J. Bacot (Paris, 1930). In the Tibetan version of the Mahāparinirvannasütra, vanaşanda is rendered as tshal-mañ-po (pp. 252-3 of the edition by Professor E. Waldschmidt, Berlin, 1950). Concerning vivara and gseb cf. also above ex. 9. In the Tibetan version of Candrakirti's Prasannapadā, nags-khrod renders tarukhanda (see the 'Glossaire sanscrit-tibétain ' appended to J. W. de Jong's Cinq chapitres de la Prasannapadā, Paris, 1949, p. 158). The rendering of khanda (sanda) by tshal in the compound taruşanda is to be found in the Tibetan version of the Udrāyañâvadäna of the Divyāvadäna (śin-ljon-pahihi tshal), see J. Nobel, Udrãyana, König von Roruka, II, Wiesbaden, 1955, p. 63, s.v. tshal.

${ }^{3}$ See above, p. 524.

- I am indebted to Dr. C. R. Bawden for kindly checking this latter reading in the Paris copy of the Peking Kanjur (Bibliothèque Nationale, Fonds Tibétain 99).

5 There would seem no need to give examples of the compound gron-gseb, which is quite common. The usage of gseb there recalls the etymological relationship between Sanskrit gräma 'village', and English 'to cram' (see M. Mayrhofer, Kurzgefasstes etymologisches Wörterbuch des Altindischen, Heidelberg, 1956, p. 353), and also that between Old English porp 'village' and Germanic torp in the meaning of ' herd', which survived in Romance languages. 
camel), which was mentioned at the beginning of this article. Apparently we are dealing here with a veiled allusion to causing pregnancy which is reminiscent of Latin implere.

Summarizing the usage of $g s e b$ it may be contended that Csoma's definitions have been confirmed, that the aspect of being close together, dense, or thronged prevails in all of them, and that the meaning of 'thicket' may perhaps have to be added to those given by Csoma.

\section{IV}

It will now be possible to consider the word family as a whole, which may serve as another example to show the ' range of sound alternations in Tibetan word families '. 1 Apart from vowel gradation which comprises the vowels $a, e, o, i, u$, we witness an alternation between initial fricatives and affricates (both of which occur also palatalized) and between a final stop and a final nasal.

The alternation between initial $s$ - and the initial affricates-see below the Perfect forms tshabs and bsabs of htshab-pa under I (a) 2 of the list of cognate words-clearly points to an archaic sts-.2 The alternation between final stop and final nasal is well known in the dental range. ${ }^{3}$ As an example in the labial range I should like to refer to rnam-pa (also rnams-pa) ' to breathe, to pant, to pant for, to desire ardently', which has already been compared by $\mathrm{J}$ (Dict., p. 134) with $r \hat{n} a b-p a$ ' to desire earnestly, to crave'. rn̂ub-pa 'to draw in', which seems to occur only in combination with dbugs 'air' in the meaning of 'to breathe', is likely to be a further cognate word.

On the semantic side, the basic idea is apparently that of a state of being close together, dense, thick, or thronged, or of causing such a state (to fill up or out, to stuff, etc.). tshab 'equivalent, substitute' forms an interesting parallel to English 'stop-gap'. From the phonetic point of view, it has a counterpart with a nasal final in tsam 'as much as, equivalent in quantity, size', etc., used in Tibetan much as Sanskrit mātra. ${ }^{4}$

In general, words with a final nasal seem to indicate more the state of coming close together, or the action of bringing this about, than the state of being close together, or the action of bringing this about.

The function of final $-s^{5}$ is worth noting in such cases as mtshams ' boundary'

1 See Asia Major, NS, I, 1949, 3-15.

2 cf. e.g., stsogs-pa instead of the usual sogs-pa in Tun-Huang texts (J. Bacot, F. W. Thomas, Ch. Toussaint, Documents de Touen-Houang relatifs à l'histoire du Tibet, Paris, 1940-6, p. 201). The same ancient form is also recorded in F. W. Thomas, Tibetan literary texts and documents, III, 1955 , p. 183, s.v. la-stsogs, side by side with las-stsogs and las-btsogs. I hope to revert to this alternation on another occasion.

3 See Jäschke, Tibetan grammar, Addenda by A. H. Francke and W. Simon, Berlin, 1929, pp. 120-1.

4 See below, p. 531, and n. 3 .

5 See Harvard Journal of Asiatic Studies, v, 1940, 387-9. 
(lit. the place where (plots of land, countries, etc.) come together), śubs 'sheath ' (the place where (object) is stuffed into), tshabs ' extreme, extremity' (lit. ' full to overflowing point '). tshom ' to doubt' is possibly ' to consider as a borderline point (case)'.

The list of cognate words which I wish to propose is as follows ${ }^{1}$ :

I Vowel $a$

(a) $-b$

(1) $g s a b, b s a b$, see $g s o b$ (II (a) 1)

(2) $\underline{h} t s h a b-p a$, Pf. tshabs, bsabs, Fut. bsab, Imp. tshob ' to pay back, repay, refund' (= 'to re-fill', see gsob, II (a) 1)

(3) tshab 'representative, equivalent, substitute' (cf. 'stopgap')

(4) tshabs (1) mostly with che, chen-po 'very great, very much', (2) 'difficulty, trouble '.2

(b) $-m$

(5) tsam ' as much as ', etc. (= ' equivalent', Sanskrit mātra ${ }^{3}$ )

(6) mtshams 'intermediate space, interstice, border, boundary-

line' (= ' coming together-place')

(7) zam-pa' bridge' (='bringing together')

II Vowelo

(a) $-b$

(1) gsob-pa, Pf. bsab, Fut. gsab (1) ' to fill out or up, to supply, complete, make up', (2) 'to pay, repay, return' (= ' to re-fill', see htshab-pa, I (a) 2)

(2) $s o b, g s o b$ 'stuffed', sob-stan ' cushion, bolster, mattress', pags-sob 'stuffed skin of an animal', señ(-gehi) sob 'the stuffed skin of a lion'

(3) $h t s h o b(s)-p a$ 'to be a deputy, representative, substitute' (see tshab, I (a) 3)

(b) $-m$

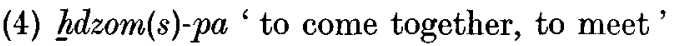

(5) tshom-pa 'to doubt, hesitate' (= 'to regard as on the borderline', see above)

(6) śom-pa, Pf. (b)śoms, bśams, Fut. bśam, Imp. (b)śom(s) ' to prepare, make ready, arrange, put in order, fit out' (cf. gsob-pa, II (a) 1)

1 Unless stated otherwise, the meanings have been taken from J's dictionary.

2 As stated above, tshabs seems to denote an extreme state, as it were ' the point when something is full to overflowing'. The example, quoted by $J$ from the Waidurya Snon-po, bud-med ho-tshabs la phan, and translated by him 'it is of use in milk-diseases of the women ', may well refer specifically to 'excessive lactation'. I noted from the Karmaśataka (Narthang Kanjur, $m D o, S a$, p. $143 A^{5}$ ) ji tsam-du tshabs che bar gyur pa de tsam-du lus las rnag khrag hdzag ste " when (the illness) reached an extreme, then matter and blood dripped from his body'. Cf. also F. Edgerton, Buddhist hybrid Sanskrit. II. Dictionary, New Haven, 1953, pp. 268-9, s.v. drdhaprahäritā, and Mahāvyutpatti, Nos. 4995 and 6776.

3 See also Asia Major, NS, ח, 1952, 194. 
III Vowel $e$

(a) $-b$

(b) $-m$

(1) gseb (see above)

(2) tshem (-po) 'seam' (cf. mtshams, I (b) 6, and III (b) 3)

(3) htshem-pa, Pf. tshems, btsems, Fut. btsem, Imp. tshems ' to sew' ( = 'to bring together')

(4) ? tshems resp. tooth (= 'seam of the mouth'?)

IV Vowel $i$

(5) ? hchems-pa, Pf. bcems, Fut. bcem ' to chew' (see III (b) 4)

(a) $-b$

(b) $-m$

(1) tshim-pa (1) 'to be content', (2) 'content, satisfied, satiated, consoled' ( = 'to be full ')

(2) hchims-pa 'to be full, to get full' (included by J from I. J. Schmidt's dictionary)

(3) ? gzim-pa ' 'to fall asleep, to sleep' (= 'close the eyes'?,

$\mathrm{V}$ Vowel $u$ cf. $h d z u m, \mathrm{~V}(b) 5$ )

(a) $-b$

(1) sub-pa, Pf. (b)subs, Fut. bsub 'to stop up, plug up, close, cork : to keep shut, closed, locked up, to stop' (= 'to stuff' ')

(2) htshub-pa, Pf. tshubs ' to be choked ', esp. ' to be drowned '

(3) bs'ub-pa 'to put into the scabbard, to sheathe' (included by J from I. J. Schmidt's dictionary) (= ' to stuff into')

(4) śubs 'case, covering sheath, paper bag', etc. (= 'place $(-s)$ to stuff into')

(b) $-m$

(5) hdzum 'to close, to shut' . . . more esp. ' to close' one's eyes, 'to shut' one's mouth (= 'to cause to come together')

1 An earlier *gdzim can be inferred from the corresponding Chinese word 寝 chiin (Karlgren,

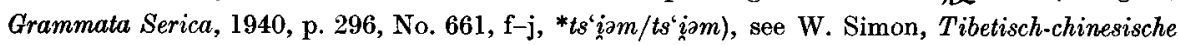
Wortgleichungen, Berlin, 1930, p. 23, No. 263. 